\title{
3,5-Bis((E)-4-methoxybenzylidene)-1- (2-morpholinoethyl)piperidin-4-one
}

\author{
Tyas Kuswardani ${ }^{1}$, Noval Herfindo ${ }^{1}\left(\mathbb{D}\right.$, Neni Frimayanti ${ }^{2}$, Rudi Hendra ${ }^{1}$ and Adel Zamri $\left.{ }^{1} * \mathbb{(}\right)$ \\ 1 Department of Chemistry, Faculty of Mathematics and Natural Sciences, Universitas Riau, Kampus Bina \\ Widya, Jalan H.R. Subrantas KM. 12.5, Pekanbaru 28293, Indonesia; tyas.kuswardani@grad.unri.ac.id (T.K.); \\ novalherfindo@gmail.com (N.H.); rudi.hendra@lecturer.unri.ac.id (R.H.) \\ 2 Department of Pharmacy, Sekolah Tinggi Ilmu Farmasi (STIFAR) Riau, Jalan Kamboja, Pekanbaru 28293, \\ Indonesia; nenifrimayanti@gmail.com \\ * Correspondence: adel.zamri@lecturer.unri.ac.id; Tel.: +62-813-6570-8146
}

Received: 25 August 2020; Accepted: 5 October 2020; Published: 8 October 2020

check for updates

\begin{abstract}
The 3,5-bis((E)-4-methoxybenzylidene)-1-(2-morpholinoethyl)piperidin-4-one (3) compound was synthesized by a two-step reaction with $92 \%$ yield. The chemical structure of compound 3 was confirmed by IR, NMR, and mass spectrometry. The title compound was screened for its anti-dengue activity against DENV2 NS2B-NS3 protease and showed 39.09\% inhibitory activity at $200 \mu \mathrm{g} / \mathrm{mL}$.
\end{abstract}

Keywords: anti-dengue; conjugated curcumin; DEN2 NS2B/NS3 protease; mono-ketone curcumin

\section{Introduction}

Dengue is a major health problem in tropical countries and the subtropics and is caused by the dengue virus (DENV). According to the World Health Organization, incidents of dengue virus infection have been increasing over the last 50 years. About 3.9 million humans in 128 countries are at risk of dengue virus infection. America, Southeast Asia and the western Pacific are said to be the most severely affected regions by this viral infection [1]. Fighting dengue infection can be done by administering drugs that have biological activity, especially anti-viral activity. The issue at hand is the absence of anti-viral vaccines or drugs on the market that are effective in preventing or treating dengue fever. Dengue cases are usually only treated to relieve symptoms with intravenous fluids [2]. Thus, research on the discovery of an effective anti-dengue treatment for all dengue strains is needed.

DENV has RNA in its genome. Five serotypes have been identified (DENV 1-5). DENV2 is the most prevalent cause of the pandemic, especially in Southeast Asia [3]. NS3 is a serine protease that has a catalytic triad of His51, Asp75 and Ser135 and NS2B as the cofactor for enhancing its protease activity $[4,5]$. NS2B/NS3 protease, as well as non-structural proteins of the dengue virus genome, have been well studied and appear to be promising targets in anti-dengue discovery [6].

One of the compounds that has diverse biological activity is curcumin derivates. Curcumin is known as a general natural product found in many regions in Indonesia. The value of this compound means that curcumin has been used in traditional medicine as an antioxidant, anti-inflammatory, antimicrobial and anticancer agent [7]. Additionally, curcumin was reported as having anti-viral activity [8]. However, curcumin is unstable because it is easily hydrolyzed at the $\beta$-diketone group, decreasing its biological activity. Using monoketone groups by the synthesis method can be a strategy for increasing its stability [9], as well as some modifications, such as adding a nitrogen-containing moiety to increase its anti-dengue activity. Balasubramanian et al. (2018) reported some natural and synthetic curcumin derivatives for inhibiting dengue virus [10]. The anti-viral activity of curcumin containing piperidone was reported for the herpes virus (hsv1) and human immunodeficiency virus (HIV-1) [11]. In recent years, we also reported synthetic curcumin from piperidone derivatives, 
where some compounds showed potential anti-dengue activity through in silico studies on the active site of NS2B/NS3 protease [12-14].

Accordingly, we synthesized monoketone curcumin from piperidone conjugated to a nitrogencontaining moiety, morpholine, to increase its anti-dengue activity. Anti-dengue activity was screened against DENV2 NS2B-NS3 protease and a molecular docking study. We hope that this study could contribute to the efforts in discovering potent anti-dengue agents.

\section{Results}

\subsection{Chemistry}

The title compound was obtained by a two-step reaction by utilizing $N$-alkylation and aldol condensation reactions, according to the reverse step of a procedure already established [13]. Initially, the amine group of 4-piperidone monohydrate hydrochloride was reacted to 4-(2-chloroethyl) morpholine hydrochloride as an alkylating agent using $\mathrm{Cs}_{2} \mathrm{CO}_{3}$ as a base to neutralize the hydrochloride, thus enabling nitrogen nucleophilicity to obtain compound 2 with a $98 \%$ yield [15]. Subsequently, compound 2 was reacted to 4-methoxybenzaldehyde in the presence of a strong base to obtain compound 3 through an aldol condensation reaction. We have found that the reversed step of this reaction leads to pure yellow crystal formation of compound 3 with a $94 \%$ yield from compound 2 or a $92 \%$ yield of total reactions without chromatographic work-up. The synthesis route is shown in Figure 1.

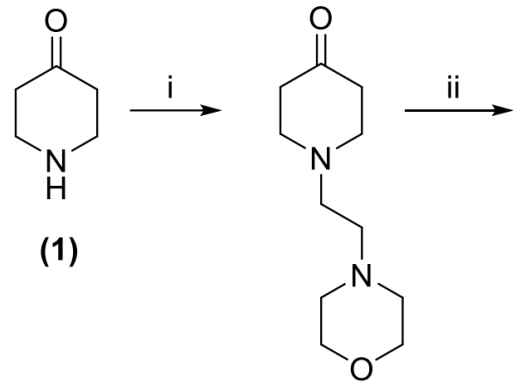

(2)<smiles>COc1ccc(/C=C2\CN(CCN3CCOCC3)C/C(=C\c3ccc(OC)cc3)C2=O)cc1</smiles>

(3)

Figure 1. Synthesis pathway of compound 3. (i) $\mathrm{CH}_{3} \mathrm{CN}, \mathrm{Cs}_{2} \mathrm{CO}_{3}, 4$-(2-chloroehtyl)morpholine hydrochloride, reflux at $80^{\circ} \mathrm{C}$; (ii) $\mathrm{C}_{2} \mathrm{H}_{5} \mathrm{OH}, \mathrm{NaOH}$, 4-methoxybenzaldehyde, reflux at $80{ }^{\circ} \mathrm{C}$.

The chemical structure of the title compound was confirmed by IR, NMR, and mass spectroscopy. The IR spectrum showed a characteristic absorption band at $1654 \mathrm{~cm}^{-1}$ for the carbonyl group $(C=O)$ and at $1244 \mathrm{~cm}^{-1}$ for the methoxy group (C-O), whereas the absence of absorption around $3200 \mathrm{~cm}^{-1}$ of the amine group indicated that alkylation of the amine group was successful. Furthermore, NMR and HRMS spectra confirmed the targeted compound 3 structure. The ${ }^{1} \mathrm{H}$ NMR spectrum showed a typical signal of two symmetrical sets of para-substituted aromatic protons around 7.03-7.47 ppm as doublets with a coupling constant of ${ }^{3} \mathrm{~J} 8.4 \mathrm{~Hz}$. The singlet signals at $7.54 \mathrm{ppm}$ and $3.87 \mathrm{ppm}$ were assigned to the protons of the $\alpha, \beta$-unsaturated ketone and the methylenes of the piperidone ring, respectively. The piperidone unit was also confirmed by a signal of ${ }^{13} \mathrm{C}-\mathrm{NMR}$ at $187.1 \mathrm{ppm}$, assigned to carbonyl carbon. The presence of the morpholine unit was shown by a triplet signal at $3.45 \mathrm{ppm}$ and $2.29 \mathrm{ppm}$ with a coupling constant of ${ }^{3} \mathrm{~J} 8.0 \mathrm{~Hz}$, while two triplets at $2.67 \mathrm{ppm}$ and $2.38 \mathrm{ppm}$ with a coupling constant of ${ }^{3} \mathrm{~J} 6.3 \mathrm{~Hz}$ indicated the bridge carbon of the morpholine unit of the piperidone ring. The HRMS spectrum of compound 3 showed $[\mathrm{M}+\mathrm{H}]^{+}$of $m / z 449.2444$ corresponding to a molecular formula of $\mathrm{C}_{27} \mathrm{H}_{33} \mathrm{~N}_{2} \mathrm{O}_{4}$ (calcd. 449.2440). 


\subsection{Anti-Dengue Activity Evaluation}

Based on high-throughput screening (HTS) data tested at a concentration of $200 \mathrm{mg} / \mathrm{mL}$, the synthesized compound exhibited 39.09\% inhibitory activity against NS2B-NS3 protease. Due to the low inhibitory activity, the $\mathrm{IC}_{50}$ was not determined. Therefore, a molecular docking simulation of compound 3 was performed to identify plausible binding modes to the DEN2 NS2B/NS3 protease, while panduratin A was used for comparison. Molecular docking was performed at the catalytic triad of the DENV protease enzyme (His51, Asp75 and Ser135) [16]. The molecular docking results of both compounds showed a strong bond to Asp75 of the protease enzyme catalytic triad (Figure 2). Compound 3 also exhibited hydrogen bonding to Gly153, but lacked interactions with His51 of the catalytic triad and Gly151 and Pro132, which are essential amino acid residues for antagonist activity against the NS2B/NS3 protease [17]. The unavailability of these interactions might be the reason compound 3 possesses low inhibitory activity against the NS2B-NS3 protease.

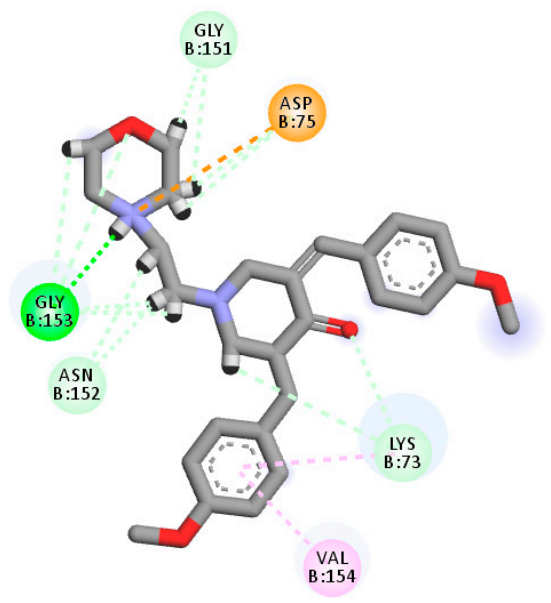

(a)

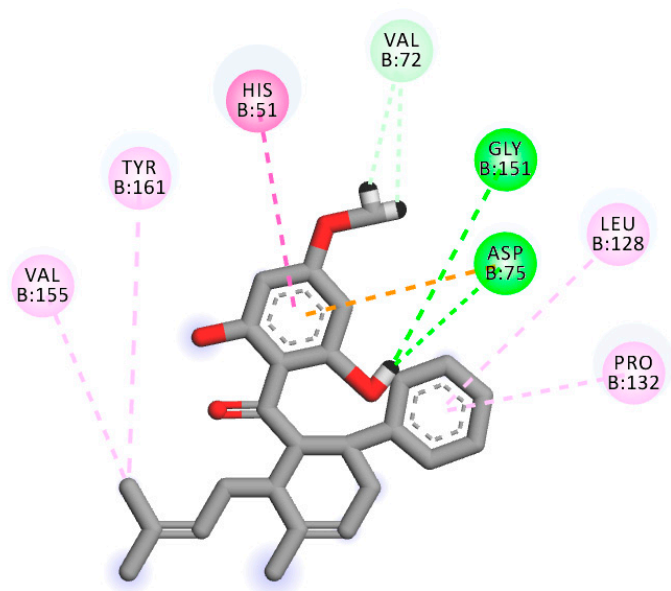

(b)

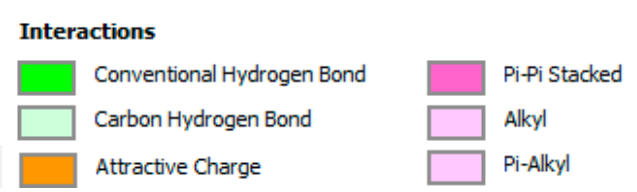

Figure 2. A $2 \mathrm{D}$ visualization of (a) compound 3 and (b) panduratin $A$ in the NS2B/NS3 protease active site.

\section{Materials and Methods}

All reagents were purchased from Sigma-Aldrich and Merck and were used without further purification. The melting point was determined on a Fisher-Johns apparatus (Fisher Scientific, Waltham, MA, USA) (uncorr). Thin Layer Chromatography (TLC) analysis was carried out using $\mathrm{GF}_{254}$ (Merck Millipore, Darmstadt, Germany) under a UV lamp 254/365 nm (Cole-Elmer ${ }^{\circledR}$, Vernon Hills, IL, USA). The UV spectrum was recorded on a Genesys ${ }^{\mathrm{TM}} 10 \mathrm{~S}$ UV-visible spectrophotometer (Thermo Scientific ${ }^{\mathrm{TM}}$, Waltham, MA, USA). The FT-IR spectrum was recorded in $\mathrm{KBr}$ powder on a Shimadzu ${ }^{\circledR}$ FT-IR Prestige-21 spectrophotometer (Shimadzu Corporation, Kyoto, Japan). The Mass spectrum was measured using Water Xevo QTOFMS instrument (Waters, Milford, MA, USA). The ${ }^{1} \mathrm{H}$ and ${ }^{13} \mathrm{C}$ NMR spectra were recorded on an Agilent ${ }^{\circledR}$ (Agilent Technologies, Santa Clara, CA, USA) at $500 \mathrm{MHz}$ and $125 \mathrm{MHz}$, respectively. 


\subsection{Synthesis of 1-(2-Morpholinoethyl)piperidin-4-one (2)}

4-piperidone monohydrate hydrochloride ( $5 \mathrm{mmol}$ ) was dissolved in $20 \mathrm{~mL}$ of acetonitrile, then cesium carbonate $(10 \mathrm{mmol})$ and 4 - $(2$-chloroehtyl)morpholine hydrochloride $(7.5 \mathrm{mmol})$ were added. Then the mixture was refluxed for $24 \mathrm{~h}$ at $80^{\circ} \mathrm{C}$. After the completion of the reaction, the mixed reaction was cooled and concentrated using a rotary evaporator to produce a crude product. The crude product was partitioned using an ethyl acetate:water system $(3 \times 15 \mathrm{~mL})$. The organic layer was taken, dried with anhydrous sodium sulfate and evaporated using a rotary evaporator. The obtained product was recrystallized with methanol to obtain compound 2 as a yellow crystal $(0.207 \mathrm{~g}, 98 \%$ yield $)$.

\subsection{Synthesis of 3,5-Bis((E)-4-methoxybenzylidene)-1-(2-morpholinoethyl)piperidin-4-one (3)}

Compound $2(3 \mathrm{mmol})$ and 4-methoxybenzaldehyde $(6 \mathrm{mmol})$ were dissolved in $10 \mathrm{~mL}$ of absolute ethanol and $10 \mathrm{~mL}$ of $1 \mathrm{~N} \mathrm{NaOH}$ was added. Then the mixture was refluxed for $5 \mathrm{~h}$ at $80^{\circ} \mathrm{C}$. After the completion of the reaction, the mixture was neutralized using $1 \mathrm{~N} \mathrm{HCl}$. The mixture was allowed to sit overnight until precipitate was formed. The precipitate was filtered and washed using $n$-hexane and demineralized water then air dried at room temperature. The obtained product was recrystallized with methanol to obtain compound 3 as a yellow crystal $(0.421 \mathrm{~g}, 94 \%$ yield). The characterization data of compound 3 are as follows: m.p. $146-147^{\circ} \mathrm{C} ;{ }^{1} \mathrm{H}-\mathrm{NMR}\left(500 \mathrm{MHz}, \mathrm{DMSO}-\mathrm{d}_{6}\right) \delta(\mathrm{ppm}): \delta 7.54(\mathrm{~s}, 2 \mathrm{H})$, $7.47(\mathrm{~d}, J=8.4 \mathrm{~Hz}, 4 \mathrm{H}), 7.03(\mathrm{~d}, J=8.4 \mathrm{~Hz}, 4 \mathrm{H}), 3.87(\mathrm{~s}, 4 \mathrm{H}), 3.81(\mathrm{~s}, 6 \mathrm{H}), 3.45(\mathrm{t}, J=8.0 \mathrm{~Hz}, 4 \mathrm{H}), 2.67(\mathrm{t}$, $J=6.3 \mathrm{~Hz}, 2 \mathrm{H}), 2.38(\mathrm{t}, J=6.3 \mathrm{~Hz}, 2 \mathrm{H}), 2.29(\mathrm{t}, J=8.0 \mathrm{~Hz}, 4 \mathrm{H}) .{ }^{13} \mathrm{C}-\mathrm{NMR}\left(126 \mathrm{MHz}, \mathrm{DMSO}-d_{6}\right) \delta(\mathrm{ppm}):$ $\delta 187.10,160.50,135.02,132.92,132.26,127.68,114.77,66.49,57.09,55.76,55.12,53.93,53.34$. HRMS (ESI): $\mathrm{m} / z$ 449.2444, $[\mathrm{M}+\mathrm{H}]^{+}$(calcd for $\left.\mathrm{C}_{27} \mathrm{H}_{33} \mathrm{~N}_{2} \mathrm{O}_{4}: 449.2440\right)$. FTIR $(\mathrm{KBr}) \bar{v}\left(\mathrm{~cm}^{-1}\right): 3073(\mathrm{~m}), 3002$ (s), 2957 (m), 1654 (s), 1598 (m), 1515 (s), 1340 (s), 1244 (s). UV-vis (EtOH) $\lambda_{\text {max }}: 366 \mathrm{~nm}$. Copies of the spectroscopy data of compound 3 (Figures S1-S5) are provided in the Supplementary Materials.

\subsection{DENV2 NS2B-NS3 Protease Inhibition Assay}

The inhibition assay was performed according to the protocol proposed by Rothan et al. [18]. A reaction mixture in a $100 \mathrm{~mL}$ aliquot was prepared by dissolving fluorogenic peptide (Boc-Gly-Arg-Arg-MCA) (10 mmol/L) and recombinant DENV2 NS2B-NS3 (0.5 mmol/L) in Tris-HCl buffer $(200 \mathrm{mmol} / \mathrm{L}, \mathrm{pH}$ 8.5). For the assay, three parallel reactions were performed viz. buffer only, buffer with enzyme and buffer with the enzyme, using $200 \mu \mathrm{g} / \mathrm{mL}$ of synthesized compound. Drug inhibitors were pre-incubated with the NS2B-NS3pro at $37^{\circ} \mathrm{C}$ for $10 \mathrm{~min}$ prior to the addition of the fluorogenic peptide substrate.

The assay mixture was incubated at the same temperature $\left(37^{\circ} \mathrm{C}\right)$ for another $1 \mathrm{~h}$. The assay conditions were validated by simultaneously running a blank control $(100 \mathrm{~mL}$ of $200 \mathrm{mmol} / \mathrm{L}$ Tris-HCl only) and a positive control (100 $\mathrm{mmol} / \mathrm{L}$ substrate BOC-GRR-MCA and $0.5 \mathrm{mmol} / \mathrm{L}$ NS2B-NS3pro in $200 \mathrm{mmol} / \mathrm{L}$ Tris- $\mathrm{HCl}$ ) and the experiment was carried out in quadruplicate. The percentage of DENV2 NS2B-NS3 protease inhibition by the peptide inhibitor was measured by fluorescence emission spectroscopy using a Tecan M1000 PRO 96-well microplate reader for emissions between 410 and $460 \mathrm{~nm}$ upon excitation at $365 \mathrm{~nm}$. The inhibitory activity was calculated according to the equation below:

$$
\begin{gathered}
\% \text { Activity }=\left[\mathrm{RFU}_{\text {sample }}-\mathrm{RFU}_{\text {blank }}\right] / \mathrm{RFU}_{\text {negative control }} \\
\% \text { Inhibition }=100 \%-\% \text { Activity }
\end{gathered}
$$

where RFU is the relative fluorescence units.

\subsection{Molecular Docking Study}

The docking study was carried out using Molecular Operating Environment 2019.0101 from Chemical Computing Group Inc. (https://www.chemcomp.com). The molecular docking simulation was performed using an ASUS E202S Netbook with Intel Celeron N3060 1.6 GHz and 2GB RAM. 
The crystal structure of DEN2 NS2B/NS3 Protease (PDB ID: 2FOM) was downloaded from Protein Data Bank (https://www.rcsb.org/structure/2FOM). The receptor protein was prepared using a structure preparation wizard. Then, the protein was energy minimized by using AMBER14:EHT force field. Ligand compounds were prepared using the same method. The docking site was set up using the site finder feature of MOE around His51, Asp75 and Ser135 amino acids residues. The compound docking was synthesized using the initial scoring methodology (London $\mathrm{dG}$ ) and the final scoring methodology (GBVI/WSA) by placement using the triangle matcher protocol and post-placement refinement was rigid receptor. The lowest bond energy conformation was taken and visualized for further analysis.

\section{Conclusions}

A novel monoketone curcumin derivative containing a morpholine moiety has been synthesized at a high yield. Compound 3 showed low inhibitory activity against the NS2B/NS3 serine protease. Thus, this compound still needs further development to increase its anti-dengue activity.

Supplementary Materials: The following are available online. Figure S1: ${ }^{1} \mathrm{H}$ NMR spectrum of 3, Figure S2: ${ }^{13} \mathrm{C}$ NMR spectrum of 3, Figure S3: Mass spectrum of 3, Figure S4: FTIR of 3, Figure S5: UV-Vis spectrum of 3.

Author Contributions: Synthesis, T.K.; NMR data analysis, T.K. and N.H.; Writing—original draft preparation, T.K. and N.H.; Writing-review and editing, R.H. and N.F.; Supervision and project administration, A.Z. All authors have read and agreed to the published version of the manuscript.

Funding: This work was funded by Direktorat Riset dan Pengabdian Masyarakat (DPRM) KEMENRISTEK DIKTI through Penelitian Dasar Unggulan Perguruan Tinggi (PDUPT) grant with contract number 407/UN.19.5.1.3/PT.01.03/2020.

Conflicts of Interest: The authors declare no conflict of interest.

\section{References}

1. World Health Organization. Dengue Vaccine: WHO Position Paper-September 2018. Available online: https://www.who.int/newsroom/factsheets/detail/dengueand-severe-dengue/ (accessed on 20 March 2020).

2. Osman, H.; Idris, N.H.; Kamarulzaman, E.E.; Wahab, H.A.; Hassan, M.Z. 3,5-Bis(arylidene)-4-piperidones as potential dengue protease inhibitors. Acta Pharm. Sin. B 2017, 7, 479-484. [CrossRef] [PubMed]

3. Galula, J.U.; Shen, W.; Chuang, S.; Chang, G.J.; Chao, D. Virus-like particle secretion and genotype-dependent immunogenicity of dengue virus serotype 2 DNA vaccine. J. Virol. 2014, 88, 10813-10830. [CrossRef] [PubMed]

4. Frimayanti, N.; Zain, S.M.; Lee, V.S.; Wahab, H.A.; Yusof, R.; Rahman, N.A. Fragment-based molecular design of new competitive dengue DEN2 NS2B/NS3 inhibitors from the components of fingerroot (Boesenbergia rotunda). In Silico Biol. 2012, 11, 29-37.

5. Yin, Z.; Patel, S.J.; Wang, W.; Chan, W.; Rao, K.R.R.; Wang, G.; Ngew, X.; Patel, V.; Beer, D.; Knox, J.E.; et al. Peptide inhibitors of dengue virus NS3 protease. Part 2: SAR study of tetrapeptide aldehyde inhibitors. Bioorg. Med. Chem. Lett. 2006, 16, 40-43. [CrossRef] [PubMed]

6. Behnam, M.A.; Nitsche, C.; Boldescu, V.; Klein, C.D. The medicinal chemistry of dengue virus. J. Med. Chem. 2016, 59, 5622-5649. [CrossRef] [PubMed]

7. Sumathi, C.S.; Rajesh, P.; Kannan, V.R. The biological potentials of indian traditional medicine, curcumin for treating human diseases. Cardiovasc. Hematol. Agents Med. Chem. 2017, 15, 1-13. [CrossRef] [PubMed]

8. Marbawati, D.; Umniyati, S.R. The effects of curcumin against dengue-2 virus based on immunocytochemistry technique. Open Trop. Med. J. 2013, 3, 95-102.

9. Zhang, Y.; Zhao, L.; Wu, J.; Jiang, X.; Dong, L.; Xu, F.; Zou, P.; Dai, Y.; Shan, X.; Yang, S.; et al. Synthesis and evaluation of a series of novel asymmetrical curcumin analogs for the treatment of inflammation. Molecules 2014, 19, 7287-7307. [CrossRef] [PubMed]

10. Balasubramanian, A.; Pilankatta, R.; Teramoto, T.; Sajith, A.M.; Nwulia, E.; Kulkarni, A.; Padmanabhan, R. Inhibition of dengue virus by curcuminoids. Antiviral Res. 2019, 162, 71-78. [CrossRef] [PubMed]

11. El-Subbagh, H.I.; Abu-Zaid, S.M.; Mahran, M.A.; Badria, F.A.; Al-Obaid, A.M. Synthesis and biological evaluation of certain $\alpha, \beta$-unsaturated ketones and their corresponding fused pyridines as antiviral and cytotoxic agents. J. Med. Chem. 2000, 43, 2915-2921. [CrossRef] [PubMed] 
12. Zamri, A.; Teruna, H.Y.; Rahmawati, E.N.; Frimayanti, N.; Ikhtiarudin, I. Synthesis and in silico studies of a benzenesulfonyl curcumin analogue as a new anti-dengue virus type 2 (DEN2) NS2B/NS3. Indones. J. Pharm. 2019, 30, 84-90.

13. Habibi, R.; Herfindo, N.; Hendra, R.; Teruna, H.Y.; Zamri, A. Synthesis and molecular docking study of 1-(3-chloropropyl)-3,5-bis((E)-4-methoxybenzylidene)piperidin-4-one as dengue virus type 2 (DEN2) NS2B/NS3 protease inhibitor candidate. Pharmacol. Clin. Pharm. Res. 2020, 5, 14-22. [CrossRef]

14. Eryanti, Y.; Herlina, T.; Zamri, A.; Halim, S.N.A.; Shiono, Y.; Syah, Y.M.; Awang, K.; Supratman, U. 3,5-Bis(2-hydroxybenzylidene)piperidin-4-one. Molbank 2014, 2014, M825. [CrossRef]

15. Valdez, C.A.; Leif, R.N.; Mayer, B.P. An Efficient, Optimized Synthesis of Fentanyl and Related Analogs. PLoS ONE 2014, 9, e108250. [CrossRef] [PubMed]

16. Noble, C.G.; Seh, C.C.; Chao, A.T.; Shi, P.Y. Ligand-Bound Structures of the Dengue Virus Protease Reveal the Active Conformation. J. Virol. 2011, 86, 438-446. [CrossRef]

17. Frimayanti, N.; Chee, C.F.; Zain, S.M.; Rahman, N.A. Design of new competitive dengue NS2B/NS3 protease inhibitors-a computational approach. Int. J. Mol. Sci. 2011, 12, 1089-1100. [CrossRef]

18. Rothan, H.A.; Abdulrahman, A.Y.; Sasikumer, P.G.; Othman, S.; Rahman, N.A.; Yusof, R. Protegrin-1 inhibits dengue NS2B-NS3 serine protease and viral replication in MK2 cells. J. Biomed. Biotechnol. 2012, 2012, 251482. [CrossRef] [PubMed]

(C) 2020 by the authors. Licensee MDPI, Basel, Switzerland. This article is an open access article distributed under the terms and conditions of the Creative Commons Attribution (CC BY) license (http://creativecommons.org/licenses/by/4.0/). 